\section{Distribution of dichlorodiphenyl- trichloroethane and hexachlorocyclohexane in urban soils and risk assessment}

\author{
Bhupander Kumar, Meenu Mishra, \\ Virendra Kumar Verma, Sanjay Kumar, \\ Chandra Shekhar Sharma
}

National Reference Trace Organics Laboratory, Central Pollution Control Board, East Arjun Nagar, Delhi, India

\section{Abstract}

This study deals with the distribution of dichlorodiphenyltrichloroethanes (DDTs) and hexachlorocyclohexanes (HCHs) in urban soils, their possible sources and probabilistic human and environmental health risk. The average concentrations of total $\mathrm{HCHs}$ and total DDTs in the soils were in the range of 0.56-8.52 $\mu \mathrm{g} \mathrm{kg} \mathrm{kg}^{-1}$ and 0.54-37.42 $\mu \mathrm{g} \mathrm{kg}^{-1}$, respectively, which were lower than guideline limits. The compositional analysis of $\mathrm{HCH}$ isomers reflects contaminations from recent usage. However, isomeric ratios between DDT, DDE and DDD, indicate anaerobic degradation of DDT and contaminations from aged DDT. Human and environmental health risk assessment was carried out by the estimation of lifetime average daily dose (LADD), incremental life time cancer risk (ILCR) and non carcinogenic health hazard quotient (HQ). LADD of total pesticides ( $\mathrm{HCH}$ and DDT) for human adults and children was ranged between $3.3 \times 10^{-9}-6.6 \times 10^{-8} \mathrm{mg}$ $\mathrm{kg}^{-1} \mathrm{~d}^{-1}$ and $1.7 \times 10^{-8}-3.4 \times 10^{-7} \mathrm{mg} \quad \mathrm{kg}^{-1} \mathrm{~d}^{-1}$, respectively. The cumulative ILCR for adults and children was ranged from $5.1 \times 10^{-9}$ to $4.6 \times 10^{-8}$ and $2.6 \times 10^{-8}$ to $2.4 \times 10^{-7}$, respectively. The HQ was ranged between $1.8 \times 10^{-6}$. $1.4 \times 10^{-4}$ and $9.5 \times 10^{-6}-7.2 \times 10^{-4}$, respectively for adults and children. These estimated ILCR and $\mathrm{HQ}$ were within the safe acceptable limits, indicating negligible risk to the residents of the study area.

\section{Introduction}

Dichlorodiphenyltrichloroethane (DDT) and hexachlorocyclohexane ( $\mathrm{HCH})$, which are highly toxic organic pollutants, also known for their long range atmospheric transport affecting regions far from their release sources. ${ }^{1}$ In May 2001, DDT was listed as one of the 12 persistent organic pollutants by the Stockholm convention. Recently in 2009, HCH isomers ( $\alpha$-HCH, $\beta$-HCH and $\gamma-\mathrm{HCH}$ ) were also included in the same category. ${ }^{2}$ In several European countries, DDT and HCH had been already prohibited or strictly restricted but these are still being produced, exported and also used in many countries around the globe due to their low cost and various uses in industries and public health programmes. DDTs and $\mathrm{HCHs}$ are a major concern because of their persistence, bioaccumulation, toxicity, and longrange environmental transport ability. They have been recognized for their potential to adversely affect wide variety of plant and animal species, including humans. ${ }^{3-6}$ These are also known as endocrine-disrupting pesticides to human beings, as their exposure through occupational and environmental means was found closely associated with cancer of the breast, ovary, prostate, testis, and thyroid in humans. ${ }^{7}$

The characteristic properties of DDT and HCH make them accumulative in soil, sediments, biota and human tissues for longer period. ${ }^{8-9}$ Due to the quantity of soil, strong sorption of these pollutants by the organic matter present in the soil and resistance to degradation, soils are generally known as the sink and source for these pollutants. ${ }^{10}$ DDT and $\mathrm{HCH}$ migrate from contaminated soils to other environmental compartments (sediment, water, atmosphere, and biota) through volatilization, erosion of soil particles, ground water or surface water transport, and bio-concentration in biota.

Human health risk assessment due to exposure to toxic contaminants had been undertaken worldwide for more than 30 years in various environmental media and foodstuff. ${ }^{11}$ Humans may get exposed to toxic contaminants, mainly through the consumption of contaminated food and occupational environments, but a significant exposure can also takes place through soil intake via ingestion, inhalation or dermal contact, because of close proximity of soil to humans. ${ }^{12-14}$ In urban areas, soils are contaminated with organic contaminants such as organochlorines (OCs), consequently adults and children may get exposed to health risk through ingestion of soil from their local areas. ${ }^{15-16}$ For this reason, it is important that soil ingestion could be considered in any risk assessments involving their potential as harmful persistent organic pollutants. ${ }^{17-19}$

Previous studies in India, have reported DDT and HCH concentrations in agricultural soils from different provinces of India such as Haryana, ${ }^{20-21}$ National Capital Region ${ }^{22-23}$ and UP, ${ }^{22,24-25}$ but work has never been conducted on urban residential soils in India. Documented research exists worldwide, to predict the risk to the residents' health, based on pesticide residue distribution in residential soils of urban and suburban areas. ${ }^{26-28}$
Correspondence: Bhupander Kumar, National Reference Trace Organics Laboratory, Central Pollution Control Board, East Arjun Nagar Delhi110032 India.

E-mail: bhupander_kumar@yahoo.com

Key words: urban soils, health risk assessment, dichlorodiphenyltrichloroethane (DDT), hexachlorocyclohexane $(\mathrm{HCH})$.

Contributions: the authors contributed equally.

Conflict of interests: the authors declare no potential conflict of interests.

Received for publication: 12 October 2012.

Revision received: 8 November 2012.

Accepted for publication: 9 November 2012.

This work is licensed under a Creative Commons Attribution NonCommercial 3.0 License (CC BYNC 3.0).

(C) Copyright B. Kumar et al., 2013

Licensee PAGEPress, Italy

Journal of Xenobiotics 2013; 3:e1

doi:10.4081/xeno.2013.e1

Therefore, this study was conducted; i) to estimate $\mathrm{HCH}$ and DDT levels in urban soils, ii) to identify the sources of the HCH and DDT, and iii) to estimate the potential of human and environmental health risks.

\section{Material and Methods}

\section{Study area and sampling}

Kurukshetra city is a developing town in Thanesar sub-district of the Haryana state of India, located at $160 \mathrm{~km}$ north of New Delhi the capital of India. This city with the population of 641 thousands covering a stretch of approximately $120 \mathrm{~km}^{2}$ area is extended between geographical coordinates of $29.97^{\circ} \mathrm{N}$ and $76.85^{\circ} \mathrm{E}$. The climatic conditions are very hot in summer $\left(>47^{\circ} \mathrm{C}\right)$ and during winters it is cold $\left(<1^{\circ} \mathrm{C}\right)$ with average annual rainfall of $582 \mathrm{~mm}$.

Sampling was carried out during June 2012 from thirteen locations covering hospital, residential, tourist places, educational and busy traffic intersections areas. Approximately, 500 grams of soil was collected from three points of each sampling location (Figure 1). After collection, materials such as pebbles, plant leaves and wood sticks were removed manually. Collected soils from each location were mixed thoroughly to ensure the true representative samples of each location. Then a sufficient quantity of soil was transferred into cleaned wide mouth amber glass Teflon lined bottles. 
Labeled containers with soil samples were transported with ice to the laboratory and kept at $4^{\circ} \mathrm{C}$ until further extraction.

\section{Chemicals and solvents}

Chemicals (anhydrous sodium sulphate, silver nitrate, potassium hydroxide, and sulphuric acid) and solvents (acetone, methanol, dichloromethane, and hexane) were purchased from Merck, India. Silica gel 60 (0.063 $0.100 \mathrm{~mm}$ ) was purchased from Supelco (Sigma-Aldrich, St. Louis, MO, USA). Silica gel, potassium hydroxide and sodium sulphate were cleaned separately with methanol, dichloromethane and acetone in Soxhlet extractor for $8 \mathrm{~h}$ each, and stored in air tight containers at $130^{\circ} \mathrm{C}$. Individual pesticide reference standard solutions of HCHs ( $\alpha-\mathrm{HCH}, \beta$ $\mathrm{HCH}, \gamma-\mathrm{HCH}$, and $\delta-\mathrm{HCH})$ and DDTs ( $p, p^{\prime}-$ DDE, $p, p^{\prime}$-DDD, $o, p^{\prime}$-DDT and $p, p^{\prime}$-DDT) were procured from Supelco (Sigma-Aldrich).

\section{Sample extraction}

Soil samples were extracted using pressurized liquid extraction procedure as per USEPA's Methods. ${ }^{29}$ Briefly, 15-20 g sample was homogenized and dried by mixing with diatomaceous earth (ASE prep DE, Dionex, USA) to get free-flowing powder. The extraction was carried out with accelerated solvent extractor (ASE-350, Dionex) ${ }^{30}$ using acetone: hexane (v/v, 1:1) in two cycles with $5 \mathrm{~min}$. static time. The ASE was operated at 1500 psi and the oven was heated to $100^{\circ} \mathrm{C}$. The extracts were concentrated to $2.0 \mathrm{~mL}$ using Rotatory Vacuum evaporator (Eyela, Tokyo, Japan).

\section{Chromatographic column cleanup}

The multilayered silica gel column chromatography was performed for fractionation and to remove interfering organic and polar species. Briefly multilayered silica gel column $(300 \times 30 \mathrm{~mm})$ was packed from bottom to upward with $2.5 \mathrm{~g}$ silica gel, $4.0 \mathrm{~g}$ silver nitrate coated silica gel, 2.5 silica gel, 4.0 basic silica gel, $2.5 \mathrm{~g}$ silica gel, $12.0 \mathrm{~g}$ acid silica and $5.0 \mathrm{~g}$ anhydrous sodium sulphate. The column was pre-rinsed with $100 \mathrm{~mL}$ n-hexane before sample was loaded. The elution of analytes was subsequently carried out using $170 \mathrm{~mL}$ hexane and concentrated to $2.0 \mathrm{~mL}$. The eluted extract was concentrated using Rotatory Vacuum evaporator and under gentle stream of pure nitrogen in Turbo Vap (Caliper, Princeton, NJ, USA) to 1.0 $\mathrm{mL}$. The extract was transferred into autosampler vial and $1 \mu \mathrm{L}$ was injected onto a gas chromatograph equipped with an electron capture detector (GC-ECD) for quantification.

\section{Instrumental analysis}

Analysis of $\mathrm{HCH}(\alpha-\mathrm{HCH}, \beta-\mathrm{HCH}, \gamma-\mathrm{HCH}$, and $\delta-\mathrm{HCH})$ and DDT ( $p, p^{\prime}-\mathrm{DDE}, \mathrm{p}, \mathrm{p}^{-}-\mathrm{DDD}$, $o, p$ '-DDT and $p, p$ '-DDT)isomers was carried out using gas chromatograph (Perkin Elmer, Clarus 500) attached with autosampler and equipped with an electron capture detector (ECD, $\left.{ }^{63} \mathrm{Ni}\right)$. Compound separations were done on Elite-1, fused silica capillary column 25 $\mathrm{m} \times 0.20 \mathrm{~mm}$ with $0.33 \mu \mathrm{m}$ particle film $(5 \%$ diphenylpolysiloxane, 95\% dimethylpolysiloxane). The column oven temperature of the gas chromatograph was initially maintained at $170^{\circ} \mathrm{C}$ and increased to $220^{\circ} \mathrm{C}\left(7^{\circ} \mathrm{C} \mathrm{min}^{-1}\right)$; temperature was further ramped to $250^{\circ} \mathrm{C}$ at

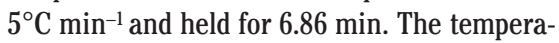
tures of injector and detector were maintained at $250^{\circ} \mathrm{C}$ and $350^{\circ} \mathrm{C}$, respectively. Nitrogen gas (purified laboratory grade) was used as carrier at the flow rate of $1.0 \mathrm{~mL} \mathrm{~min}^{-1}$.

\section{Analytical quality control}

Certified reference standard solutions were used for instrument calibration and other quality control studies. Concentrations of target compounds were determined with an external standard method comparing peak area in samples with the standards. Peak identification was conducted with the accurate retention time of each standard using five levels of calibration curves of standards ( $r^{2}$ value, 0.999). Appropriate quality assurance quality control analyses were performed. Procedural blanks were analyzed to check cross contamination and interferences (analyzed concentrations were below the method detection limit; MDL). Random duplicate samples analysis (standard deviation $<5$ ), calibration verification (standard deviation $<5$ ) and matrix-spiked studies were carried out for quality control. Samples were spiked with known working standard solutions of analytes, extracted and analyzed in the same way as the real samples. Recoveries were in the range of $86-107 \%( \pm 3$ $11 \%$ ) for each compound. Each sample was analyzed in duplicate and the average of representative data used in calculations. Concentrations below reporting limit $(0.01 \mu \mathrm{g}$ $\mathrm{kg}^{-1}$ ) were considered as zero in calculations. Moisture content of the samples was separately determined to report results on dry weight basis in $\mu \mathrm{g} \cdot \mathrm{kg}^{-1}$.

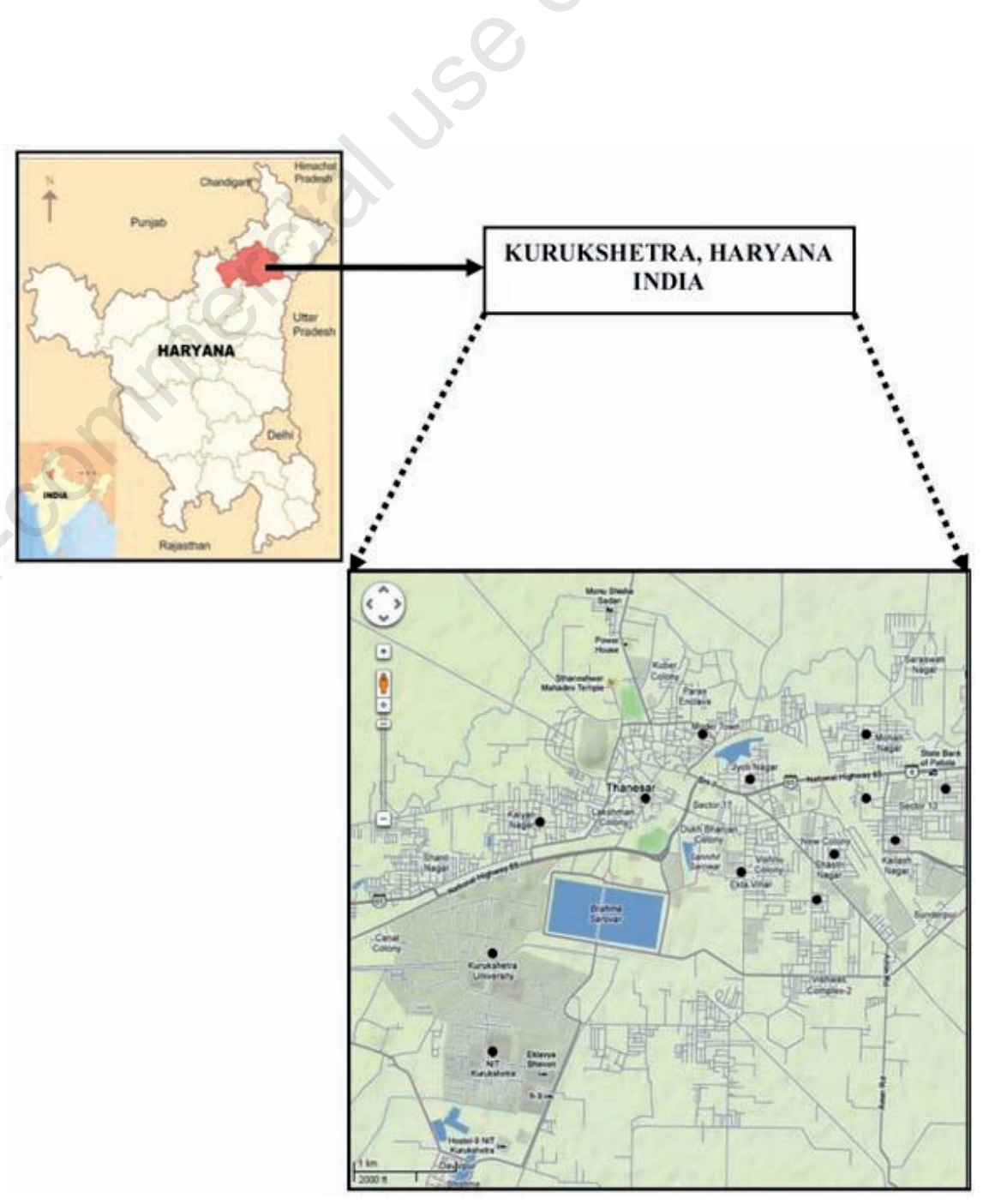

Figure 1. Map showing study area and sampling locations. 


\section{Assessment of human health risk}

Ingestion, inhalation and dermal contact are considered as the main pathways for intake of contaminants in humans. In this study, incremental lifetime cancer risk (ILCR) to humans was assessed by calculating the lifetime average daily dose (LADD) of HCHs and DDTs through ingestion of soils. ${ }^{6,31}$ The following equations were used for estimating the LADD and ILCR.

LADD $\left(\mathrm{mg} \mathrm{kg}^{-1}\right.$ day $\left.^{-1}\right)=$ $(\mathrm{Cs} \times \mathrm{IR} \times \mathrm{F} \times \mathrm{EF} \times \mathrm{ED}) /(\mathrm{BW} \times \mathrm{AT})$

Incremental Life time Cancer Risk (ILCR)= $\mathrm{LADD} \times \mathrm{CSF}$

Hazard Quotient (HQ)=LADD/RfD

Where, Cs is the pollutant concentration in soil $\left(\mathrm{mg} \mathrm{kg}^{-1}\right)$, IR is the soil ingestion rate (100 $\mathrm{mg} \mathrm{d}^{-1}$ for adult and $200 \mathrm{mg} \mathrm{d}^{-1}$ for children), $\mathrm{F}$ is the unit conversion factor, $\mathrm{EF}$ is exposure frequency (365 days/year), ED is the life time exposure duration (adults, 70 years; children, 12 years), BW is the body weight (adults, $70 \mathrm{~kg}$; children, $27 \mathrm{~kg}$ ), and AT is the averaging time for carcinogens $(E F \times E D)$. CSF and RfD is cancer oral cancer slope factor and reference dose for a particular compound intake $\left(\mathrm{mg} \mathrm{kg}^{-1} \mathrm{~d}^{-1}\right)$, respectively. ${ }^{32}$

\section{Results}

The observed concentrations of individual $\mathrm{HCH}$ and DDT isomers and their total in soils from this study were presented in Table 1. Total HCHs and DDTs concentrations were ranged between $0.56-8.52 \mu \mathrm{g} \mathrm{kg}^{-1}$ and 0.54 $37.42 \mu \mathrm{g} \mathrm{kg}^{-1}$ with averaged values of $3.00 \pm 0.54 \mu \mathrm{g} \mathrm{kg}{ }^{-1}$ and $7.88 \pm 3.07 \mu \mathrm{g} \mathrm{kg}{ }^{-1}$, respectively. The individual $\mathrm{HCH}$ isomers; $\alpha$ HCH $\left(1.07 \mu \mathrm{g} \mathrm{kg}^{-1}\right), \beta$-HCH $\left(1.40 \mu \mathrm{g} \mathrm{kg}^{-1}\right), \gamma$ HCH $\left(1.23 \mu \mathrm{g} \mathrm{kg}^{-1}\right)$, and $\delta$-HCH $(0.76 \mu \mathrm{g}$ $\mathrm{kg}^{-1}$ ) accounted for $9.1 \%, 7.9 \%, 9.5 \%$ and $1.1 \%$, respectively to total pesticides. However, DDT isomers contributed more to the total pesticides. The average concentration of $p, p^{\prime}$-DDE, $p, p^{\prime}$-DDD, $o, p^{\prime}$-DDT and $p, p^{\prime}$ DDT was $2.32 \mu \mathrm{g} \mathrm{kg}^{-1}, 4.18 \mu \mathrm{g} \mathrm{kg}^{-1}, 4.47 \mu \mathrm{g}$ $\mathrm{kg}^{-1}$ and $1.71 \mu \mathrm{g} \mathrm{kg} \mathrm{kg}^{-1}$, respectively, and accounted for $21.4 \%, 23.6 \%, 19.0 \%$ and $8.4 \%$, respectively to total pesticides. DDTs were higher than $\mathrm{HCHs}$ and contributed for $59 \%$ to total 0Cs (Figure 2). The spatial distribution of total pesticides is presented in Table 2.
Table 1. Concentration range and mean of dichlorodiphenyltrichloroethane and hexachlorocyclohexane isomers in soils $\left(\mu \mathrm{g} \mathrm{kg}^{-1}\right)$.

\begin{tabular}{lccccc} 
Compounds & \multicolumn{2}{c}{ Range } & Mean & SD & SE \\
HCH isomers & & & & \\
$\alpha$-HCH & 0.56 & 2.09 & 1.07 & 0.46 & 0.13 \\
$\beta$-HCH & 0.54 & 3.24 & 1.40 & 0.90 & 0.25 \\
$\gamma$-HCH & 0.75 & 2.24 & 1.23 & 0.41 & 0.11 \\
$\delta$-HCH & 0.57 & 0.95 & 0.76 & 0.27 & 0.07 \\
$\sum$ HCH & 0.56 & 8.52 & 3.00 & 1.93 & 0.54 \\
DDT isomers & & & & & \\
$p, p^{\prime}-$ DDE & 0.54 & 8.49 & 2.32 & 2.38 & 0.66 \\
$p, p^{\prime}-$ DDD & 0.66 & 18.03 & 4.18 & 5.81 & 1.61 \\
$0, p^{\prime}-$ DDT & 0.59 & 10.90 & 4.47 & 4.98 & 1.38 \\
$p, p^{\prime}-$ DDT & 0.55 & 7.06 & 1.71 & 2.38 & 0.66 \\
$\sum$ DDT & 0.54 & 37.42 & 7.88 & 11.07 & 3.07 \\
Total & 2.29 & 45.94 & 10.88 & 12.85 & 2.74 \\
\hline
\end{tabular}

DDT, dichlorodiphenyltrichloroethanes; $\mathrm{HCH}$, hexachlorocyclohexane; SD, standard deviation; SE, standard error=SD/Vn.

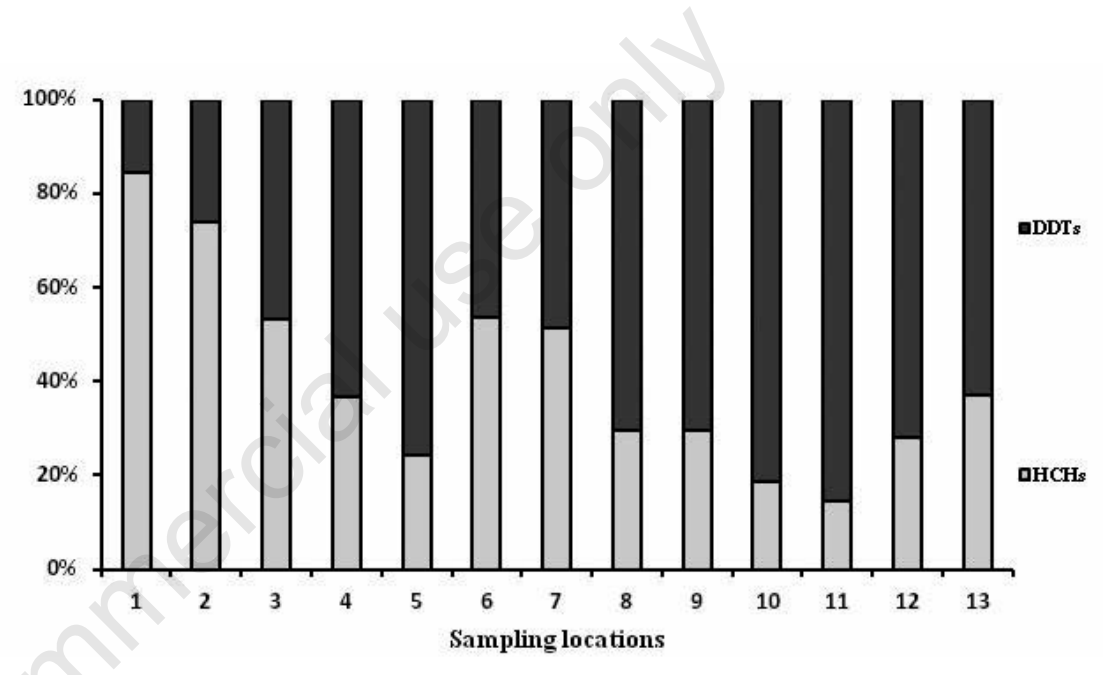

Figure 2. Percentage of dichlorodiphenyltrichloroethanes and hexachlorocyclohexanes in soils at different locations.

Table 2. Concentration of total pesticides in soils at different locations ( $\mu \mathrm{g} \mathrm{kg}-1$ ).

\begin{tabular}{lccccc}
\hline & \multicolumn{2}{c}{ Range } & Mean & SD & SE \\
& Min & Max & & \\
1 & 0.54 & 1.17 & 0.87 & 0.28 & 0.08 \\
2 & 0.88 & 1.32 & 1.12 & 0.22 & 0.06 \\
\hline 3 & 0.59 & 0.84 & 0.69 & 0.11 & 0.03 \\
4 & 0.56 & 1.61 & 1.04 & 0.40 & 0.11 \\
\hline 5 & 0.56 & 1.05 & 0.76 & 0.26 & 0.07 \\
6 & 0.54 & 1.07 & 0.78 & 0.24 & 0.07 \\
\hline 7 & 0.95 & 2.09 & 1.43 & 0.59 & 0.16 \\
\hline 8 & 0.77 & 4.34 & 2.14 & 1.59 & 0.44 \\
\hline 10 & 0.93 & 5.38 & 2.03 & 1.69 & 0.47 \\
11 & 0.95 & 18.03 & 6.56 & 6.26 & 1.73 \\
\hline 13 & 0.75 & 10.86 & 4.24 & 3.66 & 1.01 \\
\hline $5 D$ & 0.57 & 1.85 & 1.31 & 0.53 & 0.15 \\
\hline
\end{tabular}

SD, standard deviation; SE, standard error. 


\section{Discussion}

\section{Possible source identification of dichlorodiphenyltrichloroethanes and hexachlorocyclohexanes}

Compositional analysis of $\mathrm{HCH}$ and DDT isomers in the environment is used to identify the contamination sources. Generally, $\mathrm{HCH}$ is available as technical $\mathrm{HCH}$ and lindane formulations. Technical HCH has been produced and used in India as a broad-spectrum pesticide for agricultural purposes until it was banned. $\gamma$ $\mathrm{HCH}$ formulation is registered for use in public health practices to control vector borne diseases. The technical $\mathrm{HCH}$ contains the mixture of five isomers with the percentage of $55-80 \%$ $(\alpha-\mathrm{HCH}), 5-14 \%(\beta-\mathrm{HCH}), 8-15 \%(\gamma-\mathrm{HCH}), 2-$ $16 \%(\delta-\mathrm{HCH})$ and $3-5 \%(\varepsilon-\mathrm{HCH})$, and lindane formulations contains $>90 \%$ of $\gamma-\mathrm{HCH}{ }^{33}$ In this study, $\alpha$-HCH, $\beta$-HCH, and $\gamma$-HCH occupied $33 \%, 35 \%, 29 \%$ and $4 \%$, respectively of total $\mathrm{HCH}$ concentration. These changes may be due to metabolic degradation of original components of $\mathrm{HCH}$, which indicate that much of $\mathrm{HCH}$ is metabolized to the other isomers. These changes may be comparatively fast in tropical regions with high ambient temperature and humid soils, as well as higher intensity of solar radiations. ${ }^{34,35}$ Predominance of $\beta-\mathrm{HCH}$ isomer in the $\mathrm{HCH}$ compositions in the studied soils with $35 \%$ percent was much higher than that of technical $\mathrm{HCH}(5-14 \%, \beta-\mathrm{HCH})$, indicating a past (historical) technical HCH contamination, rather than current input. High $\beta$-HCH concentrations can be explained by lower vapor pressure and much slow degradation compared to other $\mathrm{HCHs}$, additionally, $\alpha-\mathrm{HCH}$ and $\gamma-\mathrm{HCH}$ can be transformed to $\beta-\mathrm{HCH} .{ }^{35}$ Walker et al. studied and reported the potential of $\gamma-\mathrm{HCH}$ transformation into other isomers of $\mathrm{HCH} . \gamma$ $\mathrm{HCH}$ may be transformed by sunlight and through biological degradation in soil into $\alpha$ HCH. ${ }^{36,37}$ The ratio of $\alpha-\mathrm{HCH}$ to $\gamma-\mathrm{HCH}$ has been widely used to identify the possible sources of HCH. Ratio between 3 and $7(\alpha / \gamma-\mathrm{HCH})$ indicates fresh input of technical $\mathrm{HCH}^{38}$ while reduced ratio of $\leq 1$, suggests lindane source. ${ }^{34}$ The estimated ratio of $\alpha / \gamma-\mathrm{HCH}$ in this study varied between 0.54-1.65 with the mean value of 1.03 and reflects usage of lindane.

The hypothesis of DDT sources to the environment was elucidated by evaluating the pattern of individual major compounds of DDTs (DDT, DDD and DDE). Therefore, the ratio between the DDT, DDE and DDD is widely used to identify the possible sources for aged or recent inputs of DDT. ${ }^{39}$ Ratio of DDT/(DDD+DDE) greater than 1 indicates DDT input in last five years, and lower ratios indicates aged DDT (microbial degradation). ${ }^{19,40}$ The observed ratio of DDT/(DDD+DDE) for this study was ranged between 0.09 to 2.39 with an average value of 0.75 , indicating that DDT inputs to this area is both past and present input but dominated by bio-transformation of DDT used in past. The vapour pressure of $o, p^{\prime}$-DDT is 7.5 times higher than $p, p^{\prime}$-DDT leading to greater volatilization of $o, p^{\prime}$-DDT to the atmosphere, ${ }^{41,42}$ and $p, p^{\prime}$-DDT metabolizes much faster in a tropical environment. In the present study, occurrence order of DDT isomers was; $o, p^{\prime}$-DDT $>p, p^{\prime}$-DDD $>p, p^{\prime}-$ DDE $>p, p$ '-DDT. Generally, technical grade DDT constitute 77.1\% $p, p^{\prime}$-DDT, $14.9 \% \quad o, p^{\prime}$-DDT, $4.0 \% p, p^{\prime}$-DDE, $0.1 \% o, p^{\prime}$-DDE, $0.3 \% p, p$ '-DDD, $0.1 \% o, p$ '-DDD, and a number of unidentified compounds (3.5\%). However, in this study we observed that $p, p^{\prime}$-DDT, $o, p$ '-DDT, $p, p^{\prime}$ '-DDE, and $p, p$-DDD occupied $12 \%, 26 \%, 30 \%$, and $33 \%$, respectively of total DDT. With contrast to DDT technical components, there are great changes because of its metabolic transformation. In soil, DDT can be transformed to stable and toxic metabolites as DDE and DDD under aerobic and anaerobic conditions, respectively. ${ }^{43,44}$ In this study, the concentration of DDD was higher than DDE (Table 1), indicating the anaerobic degradation pathway as the most probable degradation pathway of DDT. Because this area is dominated by paddy fields, where anaerobic degradation in soils may takes place. The $o, p^{\prime}$ $\mathrm{DDT} / p, p^{\prime}$-DDT ratio was reported to be $0.2 \sim 0.26$ in technical DDT and $~ 7.5$ in dicofol products. ${ }^{45}$ The ratio of $o, p^{\prime}-\mathrm{DDT} / p, p^{\prime}$-DDT in the studied soils of Kurukshetra, India was ranged from 1.48 to 2.73 with the mean of 1.92 . This ratio of $o, p$-DDT/ $p, p$-DDT was lower than that of dicofol but higher than that of technical DDT. These observations suggest contamination from aged DDT but not from dicofol.

Table 3. Life time average daily dose $\left(\mathrm{mg} \mathrm{kg}^{-1} \mathrm{~d}^{-1}\right)$ of dichlorodiphenyltrichloroethanes and hexachlorocyclohexanes for adults and children through ingestion of soils.

\begin{tabular}{|c|c|c|c|c|c|c|}
\hline \multirow[t]{2}{*}{ Compounds } & \multicolumn{3}{|c|}{ Adults } & \multicolumn{3}{|c|}{ Children } \\
\hline & Min & Max & Mean & Min & Max & Mean \\
\hline \multicolumn{7}{|l|}{$\mathrm{HCH}$ isomers } \\
\hline$\alpha-\mathrm{HCH}$ & $8.0 \times 10^{-10}$ & $3.0 \times 10^{-9}$ & $1.5 \times 10^{-9}$ & $4.2 \times 10^{-9}$ & $1.6 \times 10^{-8}$ & $7.9 \times 10^{-9}$ \\
\hline$\beta$-HCH & $7.7 \times 10^{-10}$ & $4.6 \times 10^{-9}$ & $2.0 \times 10^{-9}$ & $4.0 \times 10^{-9}$ & $2.4 \times 10^{-8}$ & $1.0 \times 10^{-8}$ \\
\hline$\gamma-\mathrm{HCH}$ & $1.1 \times 10^{-9}$ & $3.2 \times 10^{-9}$ & $1.8 \times 10^{-9}$ & $5.6 \times 10^{-9}$ & $1.7 \times 10^{-8}$ & $9.1 \times 10^{-9}$ \\
\hline$\delta-\mathrm{HCH}$ & $8.1 \times 10^{-10}$ & $1.4 \times 10^{-9}$ & $1.1 \times 10^{-9}$ & $4.2 \times 10^{-9}$ & $7.0 \times 10^{-8}$ & $5.6 \times 10^{-9}$ \\
\hline$\sum \mathrm{HCH}$ & $8.0 \times 10^{-10}$ & $1.2 \times 10^{-8}$ & $4.3 \times 10^{-9}$ & $4.1 \times 10^{-9}$ & $6.3 \times 10^{-8}$ & $2.2 \times 10^{-8}$ \\
\hline \multicolumn{7}{|l|}{ DDT isomers } \\
\hline$p, p \times-\mathrm{DDE}$ & $7.7 \times 10^{-10}$ & $1.2 \times 10^{-8}$ & $3.3 \times 10^{-9}$ & $4.0 \times 10^{-9}$ & $6.3 \times 10^{-8}$ & $1.7 \times 10^{-8}$ \\
\hline$p, p \times-\mathrm{DDD}$ & $9.4 \times 10^{-10}$ & $2.6 \times 10^{-8}$ & $6.0 \times 10^{-9}$ & $4.9 \times 10^{-9}$ & $1.3 \times 10^{-8}$ & $3.1 \times 10^{-8}$ \\
\hline$o, p \times-\mathrm{DDT}$ & $8.4 \times 10^{-10}$ & $1.6 \times 10^{-8}$ & $6.4 \times 10^{-9}$ & $4.4 \times 10^{-9}$ & $8.1 \times 10^{-8}$ & $3.3 \times 10^{-8}$ \\
\hline$p, p \times-\mathrm{DDT}$ & $7.8 \times 10^{-10}$ & $1.0 \times 10^{-8}$ & $2.4 \times 10^{-9}$ & $4.1 \times 10^{-9}$ & $5.2 \times 10^{-8}$ & $1.3 \times 10^{-8}$ \\
\hline$\sum$ DDT & $7.7 \times 10^{-10}$ & $5.3 \times 10^{-8}$ & $1.1 \times 10^{-8}$ & $4.0 \times 10^{-9}$ & $2.8 \times 10^{-7}$ & $5.8 \times 10^{-8}$ \\
\hline Total & $3.3 \times 10^{-9}$ & $6.6 \times 10^{-8}$ & $1.6 \times 10^{-8}$ & $1.7 \times 10^{-8}$ & $3.4 \times 10^{-7}$ & $8.1 \times 10^{-8}$ \\
\hline
\end{tabular}

DDT, dichlorodiphenyltrichloroethane; $\mathrm{HCH}$, hexachlorocyclohexane.

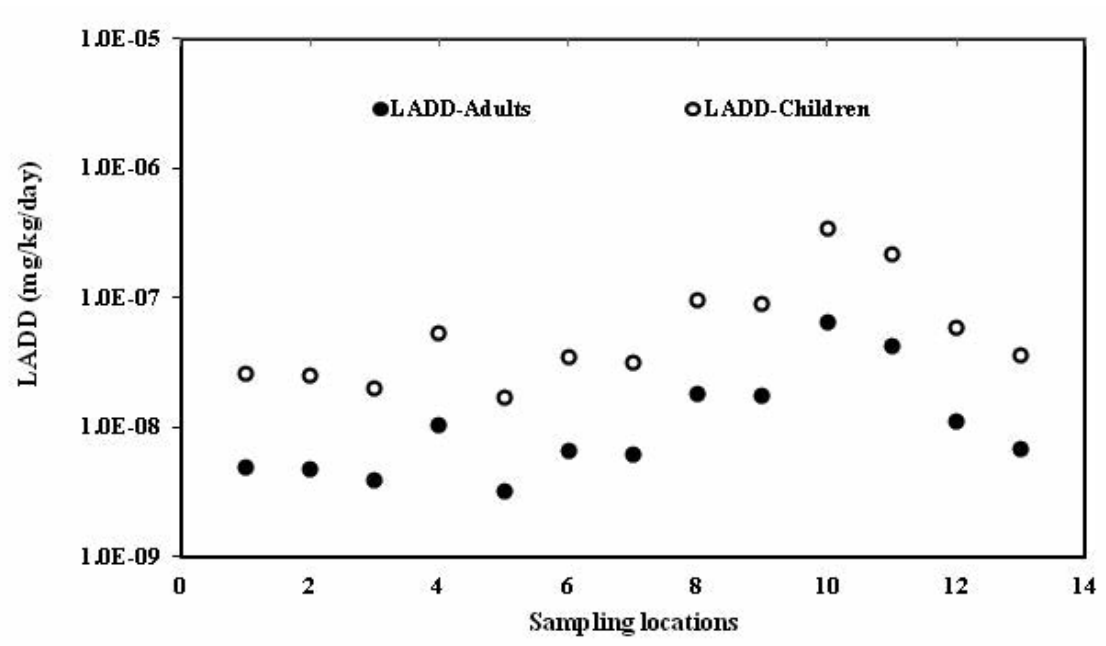

Figure 3. Life time average daily dose (LADD) organochlorines for human adults and children at different locations. 


\section{Human health risk assessment of dichlorodiphenyltrichloroethanes and hexachlorocyclohexanes}

Human health risk assessment was based on assumption that adults and children may be exposed to toxic contaminants in soil. Uptake of OCs via ingestion of soil or dust or via dermal contact may cause harmful effects on humans. Adult human and children exposure to HCHs and DDTs through soil ingestion was assessed in this study, considering the fact that adults and children remain exposed for all the days in a year during the life span of 70 years and 12 years. Human health risk was assessed by estimating the incremental LADD followed by ILCR. The lifetime average daily dose is the amount of chemical intake per $\mathrm{kg}$ of body weight per day, which may cause adverse health effects when absorbed into the body over a long period of time.

Estimated LADD of individual $\mathrm{HCH}$ and DDT isomers and their total (HCHs and DDTs) for human was presented in Table 3 and Figure 3. Total estimated LADD was ranged between $3.3 \times 10^{-10}-6.6 \times 10^{-8} \mathrm{mg} \mathrm{kg}^{-1}$ $\mathrm{d}^{-1}$ and $1.7 \times 10^{-8}-3.4 \times 10^{-7} \mathrm{mg} \mathrm{kg}^{-1} \mathrm{~d}^{-1}$, with the mean value of $1.6 \times 10^{-8} \mathrm{mg} \mathrm{kg}^{-1} \mathrm{~d}^{-1}$ and $8.1 \times 10^{-8} \mathrm{mg} \mathrm{kg}^{-1} \mathrm{~d}^{-1}$, respectively for adults and children. The average LADD of HCHs for adults and children was $4.3 \times 10^{-9} \mathrm{mg} \mathrm{kg}^{-1} \mathrm{~d}^{-1}$ (range, $8.0 \times 10^{-10}-1.2 \times 10^{-8} \mathrm{mg} \mathrm{kg}^{-1} \mathrm{~d}^{-1}$ ) and $2.2 \times 10^{-8} \mathrm{mg} \mathrm{kg}^{-1} \mathrm{~d}^{-1}$ (range, $4.1 \times 10^{-9}$ $6.3 \times 10^{-8} \mathrm{mg} \mathrm{kg}^{-1} \mathrm{~d}^{-1}$ ), respectively. However, average LADD of DDTs was $1.1 \times 10^{-8} \mathrm{mg} \mathrm{kg}^{-1}$ $\mathrm{d}^{-1}$ (range, $7.7 \times 10^{-10}-5.3 \times 10^{-8} \mathrm{mg} \mathrm{kg}^{-1} \mathrm{~d}^{-1}$ ) and $5.8 \times 10^{-8} \mathrm{mg} \mathrm{kg}^{-1} \mathrm{~d}^{-1}$ (range, $4.0 \times 10^{-9}$ $2.8 \times 10^{-7} \mathrm{mg} \mathrm{kg}^{-1} \mathrm{~d}^{-1}$ ), respectively for adults and children.

The cumulative ILCR from HCHs and DDTs for human was estimated and ranged from $5.1 \times 10^{-9}$ to $4.6 \times 10^{-8}$ (mean, $1.6 \times 10^{-8}$ ) and $2.6 \times 10^{-8}$ to $2.4 \times 10^{-7}$ (mean, $8.4 \times 10^{-8}$ ), respectively (Table 4 , Figure 4 ).The contribution of ILCR from HCHs to adults and children was $1.3 \times 10^{-8}$ (ranges, $2.6 \times 10^{-9}$ to $3.1 \times 10^{-8}$ ) and $6.6 \times 10^{-8}$ (ranges, $1.3 \times 10^{-8}$ to $1.6 \times 10^{-7}$ ), respectively. However, ILCR from DDTs was ranged between $2.6 \times 10^{-10}$. $1.6 \times 10^{-8}$ (mean, $3.5 \times 10^{-9}$ ) and $1.4 \times 10^{-9}$. $8.1 \times 10^{-8}$ (mean, $1.8 \times 10^{-8}$ ) respectively, for adults and children. This estimated ILCR was much lower than acceptable risk distribution range $\left(10^{-6}-10^{-4}\right)$. $^{32}$

Health hazard quotient (HQ) is the exact measure of the magnitude of exposure potential or a quantifiable potential for developing non-carcinogenic health effects after averaged exposure period. The quantified health HQs for total pesticides (HCHs and DDTs) through soil ingestion pathway for adults and children were ranged between $1.8 \times 10^{-6}$ to $1.4 \times 10^{-4}$ and $9.5 \times 10^{-6}$ to $7.2 \times 10^{-4}$
Table 4. Incremental life time cancer risk due to dichlorodiphenyltrichloroethanes and hexachlorocyclohexanes exposure to adults and children through ingestion of soils.

\begin{tabular}{|c|c|c|c|c|c|c|}
\hline \multirow[t]{2}{*}{ Compounds } & \multicolumn{3}{|c|}{ Adults } & \multicolumn{3}{|c|}{ Children } \\
\hline & Min & $\operatorname{Max}$ & Mean & Min & $\operatorname{Max}$ & Mean \\
\hline \multicolumn{7}{|l|}{$\mathrm{HCH}$ isomers } \\
\hline$\alpha-\mathrm{HCH}$ & $5.0 \times 10^{-9}$ & $1.9 \times 10^{-8}$ & $9.6 \times 10^{-9}$ & $2.6 \times 10^{-8}$ & $9.8 \times 10^{-8}$ & $5.0 \times 10^{-8}$ \\
\hline$\beta-\mathrm{HCH}$ & $1.4 \times 10^{-9}$ & $8.3 \times 10^{-9}$ & $3.6 \times 10^{-9}$ & $7.2 \times 10^{-9}$ & $4.3 \times 10^{-8}$ & $1.9 \times 10^{-8}$ \\
\hline$\gamma-\mathrm{HCH}$ & $1.2 \times 10^{-9}$ & $3.5 \times 10^{-9}$ & $1.9 \times 10^{-9}$ & $6.1 \times 10^{-9}$ & $1.8 \times 10^{-8}$ & $10.0 \times 10^{-9}$ \\
\hline$\delta$-HCH -* & 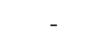 & - & - & - & - & \\
\hline$\sum \mathrm{HCH}$ & $2.6 \times 10^{-9}$ & $3.1 \times 10^{-8}$ & $1.3 \times 10^{-8}$ & $1.3 \times 10^{-8}$ & $1.6 \times 10^{-7}$ & $6.6 \times 10^{-8}$ \\
\hline \multicolumn{7}{|l|}{ DDT isomers } \\
\hline $\mathrm{p}, \mathrm{p} \times-\mathrm{DDE}$ & $2.6 \times 10^{-10}$ & $4.1 \times 10^{-9}$ & $1.1 \times 10^{-9}$ & $1.4 \times 10^{-9}$ & $2.1 \times 10^{-8}$ & $5.9 \times 10^{-9}$ \\
\hline $\mathrm{p}, \mathrm{p} \times-\mathrm{DDD}$ & $2.3 \times 10^{-10}$ & $6.2 \times 10^{-9}$ & $1.4 \times 10^{-9}$ & $1.2 \times 10^{-9}$ & $3.2 \times 10^{-8}$ & $7.4 \times 10^{-9}$ \\
\hline o,p×-DDT & $2.9 \times 10^{-10}$ & $5.3 \times 10^{-9}$ & $2.1 \times 10^{-9}$ & $1.5 \times 10^{-9}$ & $2.8 \times 10^{-8}$ & $1.1 \times 10^{-9}$ \\
\hline$p, p \times-D D T$ & $2.7 \times 10^{-10}$ & $3.4 \times 10^{-9}$ & $8.3 \times 10^{-10}$ & $1.4 \times 10^{-9}$ & $1.8 \times 10^{-8}$ & $4.3 \times 10^{-9}$ \\
\hline$\sum$ DDT & $2.6 \times 10^{-10}$ & $1.6 \times 10^{-8}$ & $3.5 \times 10^{-9}$ & $1.4 \times 10^{-9}$ & $8.1 \times 10^{-8}$ & $1.8 \times 10^{-8}$ \\
\hline Total & $5.1 \times 10^{-9}$ & $4.6 \times 10^{-8}$ & $1.6 \times 10^{-8}$ & $2.6 \times 10^{-8}$ & $2.4 \times 10^{-7}$ & $8.4 \times 10^{-8}$ \\
\hline
\end{tabular}

*Not calculated due to cancer slope oral factor (CSF) not assigned. DDT, dichlorodiphenyltrichloroethane; HCH, hexachlorocyclohexane.

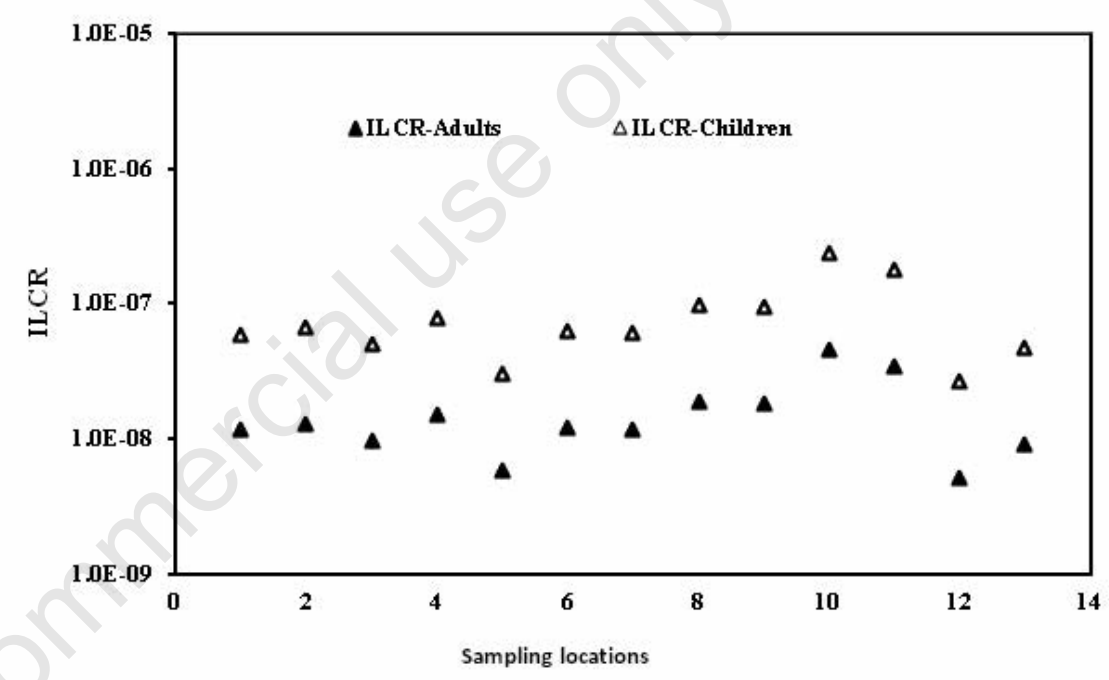

Figure 4. Incremental life time cancer risk (ILCR) to human adults and children from organochlorines at different locations.

Table 5. Non-carcinogenic health hazard due to dichlorodiphenyltrichloroethanes and hexachlorocyclohexanes exposure to adults and children through ingestion of soils.

\begin{tabular}{|c|c|c|c|c|c|c|}
\hline \multirow[t]{2}{*}{ Compounds } & \multicolumn{3}{|c|}{ Adults } & \multicolumn{3}{|c|}{ Children } \\
\hline & Min & Max & Mean & Min & Max & Mean \\
\hline \multicolumn{7}{|l|}{$\mathrm{HCH}$ isomers } \\
\hline$\alpha-\mathrm{HCH}$ & $1.0 \times 10^{-7}$ & $3.7 \times 10^{-7}$ & $1.9 \times 10^{-7}$ & $5.2 \times 10^{-7}$ & $1.9 \times 10^{-6}$ & $9.9 \times 10^{-7}$ \\
\hline$\beta-\mathrm{HCH}$ & -* & - & - & . & 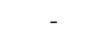 & - \\
\hline$\gamma$-HCH & $3.6 \times 10^{-6}$ & $1.1 \times 10^{-5}$ & $5.8 \times 10^{-6}$ & $1.9 \times 10^{-6}$ & $5.5 \times 10^{-5}$ & $3.0 \times 10^{-5}$ \\
\hline$\delta-\mathrm{HCH}$ & - & - & - & - & - & - \\
\hline$\sum \mathrm{HCH}$ & $1.0 \times 10^{-7}$ & $1.1 \times 10^{-5}$ & $5.1 \times 10^{-6}$ & $5.2 \times 10^{-7}$ & $5.7 \times 10^{-5}$ & $2.7 \times 10^{-5}$ \\
\hline \multicolumn{7}{|l|}{ DDT isomers } \\
\hline$p, p \times-\mathrm{DDE}$ & - & - & - & - & - & - \\
\hline$p, p \times-\mathrm{DDD}$ & - & - & - & - & - & - \\
\hline$o, p \times-\mathrm{DDT}$ & $1.7 \times 10^{-6}$ & $3.1 \times 10^{-5}$ & $1.3 \times 10^{-5}$ & $8.7 \times 10^{-6}$ & $1.6 \times 10^{-4}$ & $6.6 \times 10^{-5}$ \\
\hline$p, p \times-\mathrm{DDT}$ & $8.1 \times 10^{-6}$ & $1.0 \times 10^{-4}$ & $2.5 \times 10^{-5}$ & $4.2 \times 10^{-5}$ & $5.4 \times 10^{-4}$ & $1.3 \times 10^{-4}$ \\
\hline$\sum$ DDT & $1.7 \times 10^{-6}$ & $1.4 \times 10^{-4}$ & $2.5 \times 10^{-5}$ & $9.5 \times 10^{-6}$ & $7.2 \times 10^{-4}$ & $1.3 \times 10^{-4}$ \\
\hline Total & $1.8 \times 10^{-6}$ & $1.4 \times 10^{-4}$ & $2.5 \times 10^{-5}$ & $9.5 \times 10^{-6}$ & $7.2 \times 10^{-4}$ & $1.3 \times 10^{-4}$ \\
\hline
\end{tabular}

${ }^{*}$ Not calculated due to reference dose (RfD) not assigned. DDT, dichlorodiphenyltrichloroethane; $\mathrm{HCH}$, hexachlorocyclohexane. 
for adults and children, respectively (Table 5, Figure 5).The average HQ of HCHs, DDTs and total OCs for adults and children was $5.1 \times 10^{-6}$ and $2.7 \times 10^{-5}, 2.5 \times 10^{-5}$ and $1.3 \times 10^{-4}$, and $2.5 \times 10^{-5}$ and $1.3 \times 10^{-4}$, respectively. These estimated $\mathrm{HQ}$ values were much below the acceptable safe risk level $(\mathrm{HQ} \leq 1)$, indicating negligible risk to the residents of Kurukshetra, India.

\section{Comparison of levels of} dichlorodiphenyltrichloroethanes and hexachlorocyclohexanes in soils with other regions

$\mathrm{HCH}$ and DDT isomers have been reported as worldwide contaminants. Results of this study were compared with earlier studies on soils in India and from European and other tropical countries (Table 6). Concentrations of total HCH and total DDT were comparatively lower than other studies on soils from India and other countries. Reported concentrations of $\mathrm{HCH}$ and DDT in agriculture soil from India are available in literature but work on urban soil is not available. Therefore, this study was compared with data on agriculture soils in India. During 1990 s, concentration of $\sum \mathrm{HCH}$ and $\sum \mathrm{DDT}$ in soils from India was observed as high as 430

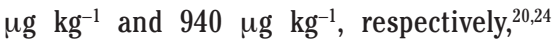
however, during 2010 s the concentrations of $\sum \mathrm{HCH}$ and $\sum \mathrm{DDT}$ were observed up to 255 $\mu \mathrm{g} \mathrm{kg}^{-1}$ and $74 \mu \mathrm{g} \mathrm{kg}^{-1}$, respectively. ${ }^{21-23}$ This decreasing trend during 1990 s to 2010 s may be due to restricted use of these compounds in India.

Concentrations obtained from this study were lower than studies reported for urban and agriculture soils from other countries. Sayed and Malik ${ }^{46}$ reported $\sum D D T$ ranging between below detection limit (BDL)-1538 $\mu \mathrm{g} \mathrm{kg}^{-1}$ and $\sum \mathrm{HCH}$ ranging between BDL-119 $\mu \mathrm{g} \mathrm{kg}^{-1}$ in urban soils from Pakistan. Surface soils from Vietnam had $\sum D D T$ and $\sum \mathrm{HCH}$ levels in the ranges of BDL-171.83 $\mu \mathrm{g} \mathrm{kg}^{-1}$ and BDL-20.57 $\mu \mathrm{g} \mathrm{kg}^{-1}$, respectively. ${ }^{47}$ Levels of $\sum$ DDT and $\sum \mathrm{HCH}$ in urban soils from different location in China were in the ranges of $0.7-972.2 \mu \mathrm{g} \mathrm{kg}-1$ and BDL-1095 $\mu \mathrm{g} \mathrm{kg}^{-1}$, respectively. ${ }^{16-26,48-52}$ However, in agriculture soils from China, the $\sum$ DDT and $\sum \mathrm{HCH}$ levels were in the ranges of $7.6-662.9 \mu \mathrm{g} \mathrm{kg}^{-1}$ and $0.2-103.9 \mu \mathrm{g} \mathrm{kg}^{-1}$, respectively. ${ }^{39-52}$

Rebeca et al. ${ }^{53}$ and Diaz-Barriga et al. ${ }^{14}$ reported $\sum D D T$ in rural soils from Chiapas (BDL-26,980 $\mu \mathrm{g} \mathrm{kg}^{-1}$ ) and Chihuahua (1-788 $\mu \mathrm{g} \mathrm{kg}^{-1}$ ) of Mexico. Ferre-Huguet et al. ${ }^{27}$ reported 126-316 $\mu \mathrm{g} \mathrm{kg}^{-1}$ of total DDT in village surface soils from Catalonia, Spain. The reported concentrations of $\sum$ DDT and $\sum \mathrm{HCH}$ in surface soils from Romania were 3.5-1542 $\mu \mathrm{g} \mathrm{kg}^{-1}$ and $0.7-90 \mu \mathrm{g} \mathrm{kg}^{-1}$, respectively.

\section{Ecological risk assessment of dichlorodiphenyltrichloroethanes and hexachlorocyclohexanes}

Ecological risk assessment is expressed as a function of environmental exposure and ecotoxicological effects. This is usually expressed as the comparison of the estimated environmental concentration with guideline concentrations. Environmental soil quality guidelines $\left(\mathrm{SQG}_{\mathrm{E}}\right)$

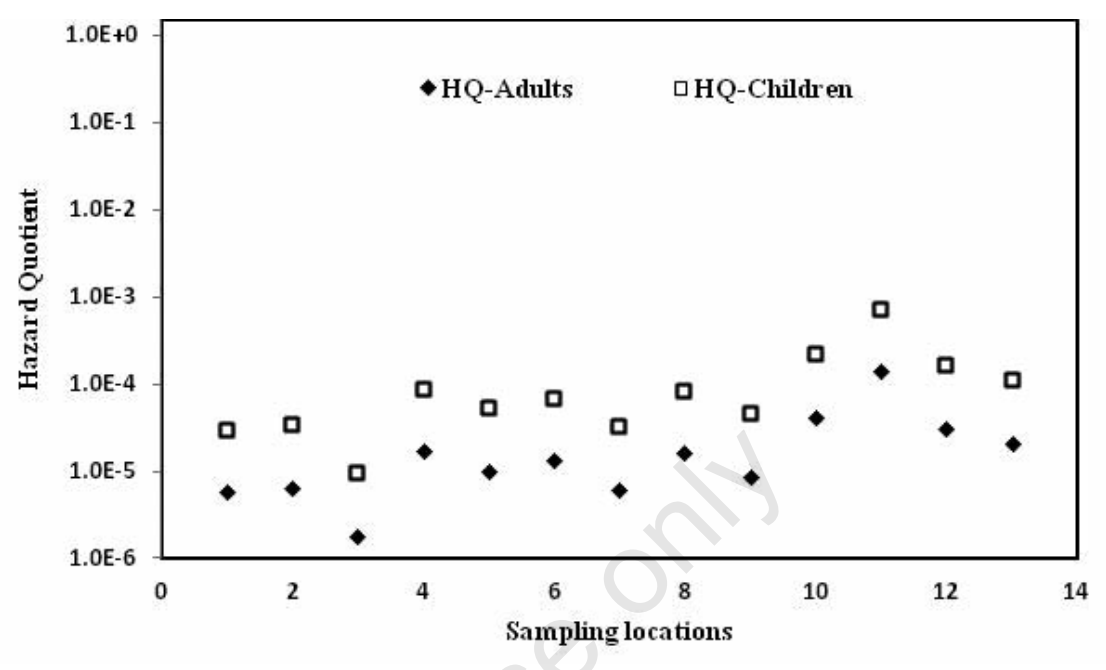

Figure 5. Health hazard quotient (HQ) for adults and children at different locations.

Table 6. Levels of dichlorodiphenyltrichloroethane and hexachlorocyclohexane in soils (mg kg-1): comparison with this study (in italics).

\begin{tabular}{|c|c|c|c|c|}
\hline Country & Land use & $\sum$ DDT & $\sum \mathrm{HCH}$ & Ref. \\
\hline Kurukshetra, India & Urban & $7.88 \pm 3.07$ & $3.00 \pm 0.54$ & Present \\
\hline Haryana, India & Paddy field & $39 \pm 12$ & $134 \pm 59$ & 20 \\
\hline Haryana, India & Agriculture & $1-66$ & $2-51$ & 21 \\
\hline NCR, India & Agriculture & - & $0.20-212.20$ & 22 \\
\hline North UP, India & Agriculture & - & $5.61-255.12$ & 22 \\
\hline NCR, India & Agriculture & $1.61 \pm 0.33$ & $34.96 \pm 5.87$ & 23 \\
\hline Farukkhabad, India & Agriculture & BDL-940 & BDL-430 & 24 \\
\hline Unnao, India & Surface & BDL-74.06 & $0.08-7.25$ & 25 \\
\hline KS Kaku, Pakistan & Urban & $0-1538$ & $0-119$ & 46 \\
\hline Hanoi, Vietnam & Surface & BDL-171.83 & BDL-20.57 & 47 \\
\hline Tianjin, China & Industrial & 73.9 & 654 & 15 \\
\hline Beijing, China & School yard & 93.68 & 2.25 & 16 \\
\hline Beijing, China & Urban park & 162.0 & 10.54 & 26 \\
\hline Guangzhou, China & Agriculture & $7.6-662.9$ & $0.2-103.9$ & 39 \\
\hline $\begin{array}{l}\text { Tianjin, China } \\
\text { Tianjin, China }\end{array}$ & $\begin{array}{c}\text { Urban } \\
\text { Suburban }\end{array}$ & $\begin{array}{c}\text { ND-616.98 } \\
0.7-972.2\end{array}$ & $\begin{array}{l}\text { ND-92.74 } \\
1.3-1095\end{array}$ & $\begin{array}{l}48 \\
49\end{array}$ \\
\hline Shanghai, China & Urban & $0.77-247.45$ & ND-10.38 & 50 \\
\hline Taiyuan, China & Urban & $1.8-100$ & $1.4-45$ & 51 \\
\hline Zhangjiagang, China & Urban/rural & 88.9 & 99 & 56 \\
\hline Guanting and Miyun, China & Watershed & ND-116.74 & ND-5.56 & 57 \\
\hline Chihuahua, Mexico & Rural & $1-788$ & - & 14 \\
\hline Catalonia, Spain & Village & $126-316$ & - & 27 \\
\hline Romania & Surface & $3.5-1542$ & $0.7-90$ & 49 \\
\hline Chiapas, Mexico & Village & ND-26,980 & - & 53 \\
\hline
\end{tabular}

DDT, dichlorodiphenyltrichloroethane; HCH, hexachlorocyclohexane; BDL, below detection limit; ND, not detected. 
are usually based on data from toxicity studies of plants and invertebrates from soils contact for different land uses. The concept of land uses does not provide adequate protection for ecological receptors. Therefore, soil quality guidelines for residential/parkland and agricultural land uses are based on models designed to protect primary, secondary, and tertiary consumers from ingestion of contaminated soil and food. ${ }^{54}$ The soil and food ingestion guidelines are the lowest of three values designed to protect primary, secondary, and tertiary consumers from ingestion of contaminated soil and food. First value is modeled for the protection of primary consumers (soil $\rightarrow$ plant $\rightarrow$ herbivore pathway), second value is modeled for the protection of secondary consumers (soil $\rightarrow$ plant $\rightarrow$ herbivore $\rightarrow$ predator pathway) and the third value is modeled for the protection of tertiary consumers (soil $\rightarrow$ invertebrate $\rightarrow$ secondary consumer $\rightarrow$ predator pathway).

For all land uses, the preliminary soil contact values are also called threshold effects concentration (TEC). TECs are those, above which adverse effects are not expected or rarely occur on the majority of organisms and soils are considered to be clean to marginally low polluted. Environmental guidelines for HCHs and DDTs in soil and sediments have not yet been established in India. Therefore, recommended soil quality guidelines from National Oceanography and Atmospheric Administration USA and Canadian government were applied in this study for evaluation of ecotoxicological effects of HCHs and DDTs. The Canadian government established guideline concentration of total DDT as $700 \mu \mathrm{g} \mathrm{kg}^{-1}$ (agricultural and residential/parkland use) and $12,000 \mu \mathrm{g} \mathrm{kg}^{-1}$ (commercial and industrial land use). ${ }^{55}$ However, NOAA recommended $\mathrm{HCH}$ target values of $20 \mu \mathrm{g} \mathrm{kg}^{-1}$ for agricultural land use and $2000 \mu \mathrm{g} \mathrm{kg}^{-1}$ for urban park and residential land use. ${ }^{56}$ The observed concentrations of total DDT and total HCH in soils from the studied area of Kurukshetra, India were $7.88 \pm 3.07 \mu \mathrm{g} \mathrm{kg}{ }^{-1}$ and $3.00 \pm 0.54 \mu \mathrm{g} \mathrm{kg}$, respectively, which were much lower than stipulated guideline values for the protection of environmental and human health.

The quality of soil may be classified on the basis of the concentration of both $\mathrm{HCHs}$ and DDTs. ${ }^{16}$ Low polluted (below $50 \mu \mathrm{g} \mathrm{kg}{ }^{-1}$ ), light polluted (50-500 $\left.\mu \mathrm{g} \mathrm{kg}^{-1}\right)$, moderate polluted (500-1000 $\left.\mu \mathrm{g} \mathrm{kg}^{-1}\right)$, and heavily polluted $\left(>1000 \mu \mathrm{g} \mathrm{kg}^{-1}\right.$ ). Thus, the soils of Kurukshetra, Haryana, India may be classified as low polluted soil with HCHs and DDTs.

\section{Conclusions}

DDTs and HCHs in soils collected from near residential, roadside, school, hospital and park- land areas of Kurukshetra Haryana, India were determined in this study. The results provided useful information on DDT and $\mathrm{HCH}$ residues in soil of a tropical developing city in India, their probable sources and probabilistic human and environmental health risk. The concentrations of DDT sand total HCHs were below the guideline limits set by the USA and Canadian government, therefore soils may be classified as low polluted. The predominance of $\beta$-HCH and $\alpha / \gamma$ $\mathrm{HCH}$ ratio in $\mathrm{HCHs}$ suggested that they were from historical contamination of HCHs. The estimated isomeric ratio between DDT, DDE and DDD isomers indicates anaerobic degradation of DDT and contaminations from aged DDT but not from dicofol products.

LADD, ILCR and non-carcinogenic health HQ estimates shows low or negligible health risk for humans and environment in this area of study.

\section{References}

1. Wania F, Mackay D. Tracking of distribution of persistent organic pollutants. Environ Sci Technol 1996;30:390-6.

2. UNEP (United Nations Environment Programme). Report of the Conference of the Parties of the Stockholm Convention on Persistent Organic Pollutants on the work of its fourth meeting UNEP/ POPS/COP4/38; 8 May 2009. Available from: http://chm.pops.int/Convention/ ConferenceoftheParties(COP)/Meetings/C OP4/COP4Documents/tabid/531/ct//Downl oad/mid/1874/Default.aspx?id=401

3. Iwata H, Tanabe S, Sakai N, Nishimura A, Tatsukawa R. Geographical distributions of persistent organochlorines in air, water and sediments from Asia and Oceania and their implications for global redistribution from lower latitudes. Environ Poll 1994;85:15-33.

4. El-Shahawi MS, Hamza A, Bashammakh AS, Al-Saggaf WT. An overview on the accumulation, distribution, transformations, toxicity and analytical methods for the monitoring of persistent organic pollutants. Talanta 2010;80:1587-97.

5. ATSDR (Agency for Toxic Substances and Disease Registry). Toxicological profile for DDT, DDE, and DDD. Atlanta, GA: US Public Health Service; 2008.

6. ATSDR. Toxicological profile for hexachlorocyclohexanes. US Department of Health \& Human Services Public Health Service Agency for Toxic Substances and Disease Registry; 2005. Available from: http://www.atsdr.cdc.gov/toxprofiles/tp43. html

7. Ejaz S, Akram W, Lim CW, Lee JJ, Hussain I. Endocrine disrupting pesticides: A lead- ing cause of cancer among rural people in Pakistan. Exper Oncol 2004;26 98-105.

8. Nakata H, Kawazoe M, Arizono K, Abe S, Kitano T, Shimada H, et al. Orga-nochlorine pesticides and polychlorinated biphenyl residues in foodstuffs and human tissues from China: status of contamination, historical trend, and human dietary exposure. Arch Environ Contam Toxicol 2002;43:473-80.

9. Ferencz L, Balog A. A pesticide survey in soil, water and foodstuffs from central Romania. Carpathian J Earth Environ Sci 2010;5:111-8.

10. Bidleman TF, Leone AD, Wong F, Van VL, Szeto S, Ripley BD. Emission of legacy chlorinated pesticides from agricultural and orchard soils in British Columbia, Canada. Environ Toxicol Chem 2006;25: 1448-57.

11. National Research Council (NRC). Pesticides in the diets of infants and children. Washington, DC: National Academic Science Research Council; 1993.

12. Morra P, Bagli S, Spadoni G. The analysis of human health risk with a detailed procedure operating in a GIS environment. Environ Int 2006;32:444-54.

13. Damalas CA, Eleftherohorinos IG. Pesticide exposure, safety issues and risk assessment indicators. Int $\mathrm{J}$ Environ Res Public Health 2011;8:1402-19.

14. Diaz-Barriga MF, Trejo-Acevedo A, Betanzos AF, Espinosa-Reyes G, AlegriaTorres JA, Perez Maldonado IN. Assessment of DDT and DDE levels in soil, dust, and blood samples from Chihuahua, Mexico. Arch Environ Contam Toxicol 2012;62:351-8.

15. Li J, Lu YL, Shi YJ, Wang TY, Wang GA, Luo W, et al. Environmental pollution by persistent toxic substances and health risk in an industrial area of China. J Environ Sci 2011;23:1359-67.

16. Wang X, Wang D, Qin X, Xu X. Residues of organochlorine pesticides in surface soils from college school yards in Beijing, China. J Environ Sci 2008;20:1090-6.

17. Gough M. Human exposures from dioxin in soil - a meeting report. J Toxicol Environ Health 1991;32:205-35.

18. Abrahams PW. Soils: their implications to human health. Sci Total Environment 2002;291:1-32.

19. Li J, Zhang G, Qi S, Li X, Peng X. Concentrations, enantiomeric compositions, and sources of $\mathrm{HCH}$, DDT and chlordane in soils from the Pearl River Delta, South China. Sci Total Environment 2006;372: 215-24.

20. Kumari B, Singh R, Madan VK, Kumar R, Kathpal TS. DDT and HCH compounds in soils, ponds, and drinking water of Haryana, India. Bull Environ Contam 
Toxicol 1996;57:787-93.

21. Kumari B, Madan VK, Kathpal TS. Status of insecticide contamination of soil and water in Haryana, India. Environ Monit Assess 2008;136:239-44.

22. Om Prakash, Suar M, Raina V, Dogra C, Pal R, Rup Lal. Residues of Hexachlorocyclohexane isomers in soil and water samples from Delhi and adjoining areas. Curr Sci 2004;87:73-7.

23. Kumar B, Kumar S, Gaur R, Goel G, Mishra M, Singh SK, et al. Persistent organochlorine pesticides and polychlorinated biphenyls in intensive agricultural soils from North India. Soil Water Res 2011;6:190-7.

24. Agnihotri NR, Kulshrestha G, Gajbhiye VT, Mohapatra SR, Singh SB. Organochlorine insecticide residues in agricultural soils of the Indo-Gangetic plain. Environ Monit Assess 1996;40: 279-88.

25. Singh KP, Malik A, Sinha S. Persistent organochlorine pesticide residues in soil and surface water of northern IndoGangetic alluvial plains. Environ Monit Assess 2007;125:147-55.

26. Li XH, Wang W, Wang J, Cao XL, Wang XF, Liu JC, et al. Contamination of soils with organochlorine pesticides in urban parks in Beijing, China. Chemosphere 2008;70:1660-8.

27. Ferre-Huguet N, Bosch C, Lourencetti C, Nadal M, Schuhmacher M, Grimalt J0, et al. Human health risk assessment of environmental exposure to organochlorine compounds in the Catalan stretch of the Ebro River, Spain. Bull Environ Contam Toxicol 2009;83:662-7.

28. Quiros-Alcala L, Bradman A, Nishioka M, E-Harnly M, Hubbard A, E-McKone T, et al. Pesticides in house dust from urban and farmworker households in California: an observational measurement study. Environ Health 2011;10:19.

29. United States Environmental Protection Agency (USEPA). Method 3545: SW-846. Washington, DC: US Government Printing Office; 1995.

30. Dionex,1999. Application Note 352. Sunnyvale, CA: Dionex; 1999.

31. United States Environmental Protection Agency (USEPA). Risk assessment guidance for superfund. Human health evaluation manual (Part A). EPA 540-1-89002,1989. Washington, DC: US Government Printing Office; 1989.

32. United States Environmental Protection Agency (USEPA). http://www.epa.gov/ reg3hwmd/risk/human Accessed: 20.9 . 2012.
33. Qui XH, ZhuT, LiJ, Pan HS, Li QL, Miao GF, et al. Organochlorine pesticides in air around the Taihu Lake, China. Environ Sci Technol 2004;38:1368-74.

34. Willett L, Ulrich EM, Hites HA. Differential toxicity and environmental fates of Hexachlorocyclohexane isomers. Environ Sci Technol 1998;32:2197-207.

35. Walker K, Vallero DA, Lewis RG. Factors influencing the distributionof lindane and other hexachlorocyclohexanes in the environment. Environ Sci Technol 1999;33: 4373-8.

36. Benezet HJ, Matsumura F. Isomerization of (gamma)-BHC to (alpha)-BHC in the environment. Nature 1973;243:480-1.

37. Malaiyandi M, Shah S. Evidence of photoisomerization of hexachlorocyclohexaneisomers in the ecosphere. J Environ Sci Health 1980;(A19):887-910.

38. Yang Y, Li D, Mu D. Levels, seasonal variations and sources of OCPs in ambient air of Guangzhou, China. Atm Environ 2008; 42:677-87.

39. Gao F, Jia J, Wang X. Occurrence and ordination of dichlorodiphenyltrichloroethaneand hexachlorocyclohexane in agricultural soils fromGuangzhou, China. Arch Environ Contam Toxicol 2008;54:155-66.

40. Tavares TM, Beretta M, Costa MC. Ratio of DDT/DDE in the all Saints Bay, Brazil, and its use in environmental management. Chemosphere 1999;38:1445-52.

41. Spencer W, Cliath MM. Volatility of DDT and related compounds. J Agric Food Chem1972;20:645-9.

42. World Health Organization (WHO). DDT and its derivatives-environmental aspects, 1989. Environ Health Criteria 83. Geneva: World Health Organization; 1989.

43. Atlas E, Giam CS. Ambient concentration and precipitation scavenging of atmospheric organic pollutants. Water Air Soil Pollut 1988;38:19-36.

44. Aislabie JM, Richards NK, Boul HL. Microbial degradation of DDT and its residues-a review. New Zeal J Agric Res 1997;40:269-82.

45. Talekar NS, Sun LT, Lee EM, Chen JS. Persistence of some insecticides in subtropical soils. J Agric Food Chem 1977;25:348-52.

46. Syed JH, Malik RN. Occurrence and source identification of organochlorine pesticides in the surrounding surface soils of the Ittehad Chemical Industries Kalashah Kaku Pakistan. Environ Earth Sci 2011;62: 1311-21.

47. Toan VD, Thao VD, Walder J, Schmutz HR, Ha CT. Contamination by selected organochlorine pesticides (OCPs) in surface soils in Hanoi, Vietnam. Bull Environ Conta Toxicol 2007;78:195-200.

48. Lv J, Shi R, Cai Y, Liu Y, Wang Z, Feng J, et al. Assessment of 20 organochlorine pesticides (OCPs) pollution in suburban soil in Tianjin, China. Bull Environ Contam Toxicol 2010;85:137-41.

49. Cai QY, Mo CH, Wu QT, Katsoyiannis A, Zeng QY. The status of soil contamination by semivolatile organic chemicals (SVOCs) in China: a review. Sci Total Environ 2008;389:209-24.

50. Jiang YF, Wang XT, Jia Y, Wang F, Wu MH, Sheng GY, et al. Occurrence, distribution and possible sources of organochlorine pesticides in agricultural soil of Shanghai, China. J Hazard Mater 2009;170:989-97.

51. Fu S, Cheng HX, Liu YH, Xu XB. Levels and distribution of organochlorine pesticides in various media in a mega-city, China. Chemosphere 2009;75:588-94.

52. Hu W, Huang B, Zhao Y, Sun W, Gu Z. Organochlorine pesticides in soils from a typical alluvial plain of the Yangtze River delta region, China. Bull Environ Contam Toxicol 2011;87:561-6.

53. Rebeca IM, Diaz-Barriga F, BatresEsquivel LE, Perez-Maldonado IN. Assessment of the levels of DDT and its metabolites in soil and dust samples from Chiapas, Mexico. Bull Environ Contam Toxicol 2011;86:33-7.

54. Canadian Council of Ministers of the Environment (CCME). A protocol for the derivation of environmental and human health soil quality guidelines. Winnipeg: Canadian Council of Ministers of the Environment; 1996.

55. Canadian Council of Ministers of the Environment (CCME). Canadian soil quality guidelines for the protection of environmental and human health: Summary tables Updated September, 2007. In: Canadian environmental quality guidelines. Winnipeg: Canadian Council of Ministers of the Environment; 1999.

56. Buckman MF. NOAA screening quick reference tables (SQuiRTs), HAZMAT REPORT 99-1 (updated Feb 2004), Seattle Washington Coastal Protection and Restoration Division, National Oceanography and Atmospheric Administration; 1999. p 12.

57. Hu W, Lu Y, Wang G, Wang T, Luo W, Shi Y, et al. Organochlorine pesticides in soils around watersheds of Beijing reservoirs: A case study in Guanting and Miyunreservoirs. Bull Environ Contam Toxicol 2009;82:694-700. 